\title{
Ulusal Dinamik Rüzgâr Erozyonu Modeli ve İzleme Sistemi Bitki Örtüsü Parametresinin Belirlenmesi
}

\author{
Reșat AKGÖZ1 , * \\ Kenan INCE² \\ 'Ankara Üniversitesi, Ziraat Fakültesi, Toprak Bilimi ve Bitki Besleme Bölümü, Ankara \\ ${ }^{2}$ Çölleșme ve Erozyonla Mücadele Genel Müdürlüğü, Ankara
}

Günay ERPUL'

\begin{abstract}
*Sorumlu yazar e-mail (Corresponding author e-mail): resatakgoz@gmail.com
Geliș tarihi (Received) : 03.10.2019

Kabul tarihi (Accepted): 19.12.2019

DOI: $10.21657 /$ topraksu.628988
\end{abstract}

\section{Öz}

Sürdürülebilir Toprak Yönetimi (STY) ve Sürdürülebilir Arazi Yönetimi (SAY) kapsamında sorun-temelli arazi kullanımı planlamalarının yapılarak sağlıkı bir șekilde yönetilebilmesi için rüzgâr erozyonuna maruz kalan alanların konumları ve etkilenme düzeylerinin niceliksel olarak belirlenmesi gerekmektedir. Bu bağlamda Türkiye ölçeğinde rüzgâr erozyonu tahmin modelleme çalıșmaları 'Ulusal Dinamik Rüzgâr Erozyonu Modeli ve İzleme Sistemi (UDREMis)' ile bașlatılmıștır. UDREMis modelinin getirdiği zamansal ve konumsal tahmin esnekliği ile elde edilen bilgiler SAY, STY ve Arazi Tahribatının Dengelenmesi (ATD) çalıșmalarında doğal kaynak planlamalarında altlık olarak kullanıma hazır hale getirilmiștir. Rüzgâr erozyonunun tahmin edilebilmesi ve izlenmesi amacıyla, dinamik ve güncellenebilir veri tabanlarının kullanılabileceği Yenilenmiș Rüzgâr Erozyonu Eșitliği (YREE) modeli seçilerek UDREMis sistemi geliștirilmiștir. İklim, toprak, bitki örtüsü, pürüzlülük ana parametrelerinden olușan YREE modelinin bitki örtüsü parametresi hakkındaki bilgilere bu yayında yer verilmiștir. Bitki örtüsüne bağı toprak kayıpları oranının belirlendiği bu çalıșmada, 1440 adet Landsat 8 uydu görüntüsü ișlenerek NDVI analizleri yardımıyla bitki örtüsü kapalııkları ve bunlardan yola çıkılarak YREE modeli vejetasyon oranı ve toprak kayıpları oranı belirlenmiștir. Çalıșma ile Temmuz ayından sonra ülkemizde hasat sonrası kapalıığın giderek düștüğü ve rüzgâr erozyonuna duyarlı hale geldiği gözlenmiștir. Küresel iklim değișikliği ile yıllık yağıș ve sıcaklık seyri değișmektedir. Buna bağlı olarak geç kalan sonbahar yağıșları araziyi rüzgâr erozyonuna açık hale getirmektedir. UDREMis sistemi sürekli olarak dönemsel uydu görüntüleri ile desteklemekte ve buna bağlı olarak arazi kullanım değișimlerinin zamansal ve konumsal olarak rüzgâr erozyonu üzerindeki etkileri analiz edilebilmektedir.

Anahtar Kelimeler: Arazi bozulumu, normalize edilmiș fark bitki örtüsü indeksi, rüzgâr erozyonu, yenilenmiș rüzgâr erozyonu eșitliği (YREE)

\section{Determination of National Dynamic Wind Erosion Model and Monitoring System Vegetation Parameter}

\begin{abstract}
In order to make land use planning within the scope of Sustainable Soil and Land Management (SSM\&SLM), the locations and levels of impact of areas exposed to wind erosion need to be quantified. In this context, wind erosion prediction modeling studies on the country scale were initiated with the "National Dynamic Wind Erosion Model and Monitoring System (UDREMIS). Information obtained by the temporal field estimation flexibility introduced by the UDREMIS model will be used as underlining in SLM, SSM and Land Degradation Neutrality (LDN) projects. The UDREMIS system was developed by selecting the RWEO model where dynamic, updatable databases can be used in the national dimension
\end{abstract}


in order to predict and monitor wind erosion in the national scale. RWEO model consists of climate, soil, topography, vegetation, management parameters; information about the vegetation parameter is given in this publication. In this study, 1440 Landsat 8 satellite images were processed and with the help of NDVI Analyses, the canopy covers and vegetation rates were determined. Vegetation and soil loss rate were determined by starting from vegetation cover. With the study, it was observed that postharvest vegetation cover, especially on dry farmland after July, gradually fell and became susceptible to wind erosion. With global climate change, delayed rains due to the shift in the seasons affect the canopy cover at negative rate, increasing the sensitivity of the lands to wind erosion. The UDREMIS system is continuously fed by periodic satellite images, both temporal and positional effects of land use changes on wind erosion can be analyzed.

Keywords: Land degradation, normalized difference vegetation index (NDVI), revised wind erosion equation (RWEQ), wind erosion

\section{GíRiș}

Dünya genelinde en önemli çevresel problemlerin bașında șüphesiz arazi bozulumu gelmektedir. 'Küresel İklim Değișikliği' ve artan insan baskısı ile birlikte erozyon, kuraklık, arazi bozulumu ve çölleșme gibi çevresel sorunlar hızlanarak artmıștır. Bu süreçler, hâlihazırda oldukça kısıtı olan temiz su kaynaklarının azalarak kirlenmesine, tarım, orman ve mera varlığının yok olmasına veya niteliklerini kaybetmesine, toprağın üretim kapasitesinin azalmasına yol açmaktadır.

Türkiye'de toprak ve su korumalı tarım sistemlerinin yaygınlașmamıș olması, doğal kaynakların sürdürülebilir kullanımı ile ilgili politikaların eksikliği, așırı otlatma, ormansızlașma, geleneksel tarım uygulamaları, yanlıs sulama gibi etmenler arazi bozulumu süreçlerini tetiklemektedir (Erpul vd., 2012). Özellikle bu gibi alanlarda toprak üstü örtünün uzaklaștırılması önemli bir arazi bozulumu nedeni olan rüzgâr erozyonunun șiddetini ve etkilediği alanların miktarını artırması muhtemeldir.

Arazi bozulmasına en duyarlı alanlar kurak, yarı kurak ve yarı nemli bölgeler olup (Stroosnijder, 2007), özellikle rüzgâr erozyonu bu bölgelerdeki hâkim bozulma süreçlerinden biridir (Lal, 1990). İnsan etkisiyle hız kazanan bu doğa olayı, uygun atmosferik koșullar altında gerçekleștiğinde toprak taneciklerini parçalayarak oldukça uzak mesafelere kolaylıkla tașlyabilmektedir (Reich vd., 2000). Özellikle mineral ve organik madde kapsamları açısından oldukça zengin olan üst toprak katmanının etkilendiği bu süreç sonucunda, verimli olan katmanın ortamdan uzaklașması ile toprakların tarımsal üretim potansiyeli önemli ölçüde azalmaktadır.

Yapılan çalıșmalara göre dünya genelinde 548 milyon ha alan rüzgâr erozyonu tehlikesi ile karșı karșıyadır. Asya kıtası 222 milyon ha ile en yüksek, Afrika kıtası 186 milyon ha ile ikinci sırada yer almaktadır (Lal, 2001).

Türkiye'de ülkesel ölçekte yapılan mekânsal analizlere göre rüzgâr erozyonu potansiyeline sahip toplam alanın \%7.54'ünde çok șiddetli rüzgâr erozyonunun yașanabileceği belirtilmiștir. Bu oranın alansal karșilığı ise 1292771 ha olarak hesaplanmıștır. Alansal olarak çok șiddetli sınıfında en yüksek rüzgâr erozyonunun sırasıyla DicleFırat, Kızılırmak ve Konya havzalarında en az ise sırasıyla Coruh, Doğu Karadeniz ve Batı Karadeniz havzalarında olduğu belirlenmiștir. (İnce vd., 2019).

Ülkemizde rüzgâr erozyonu çalıșmaları uzun süre parsel düzeyinde yapılmıștır. Bunun nedenleri genellikle çalıșmaların doğrudan arazi ölçümleri șeklinde yapılması, bölgesel çalıșmalarda arazi çalıșması giderlerinin yüksek olması ve bölgesel düzeyde model çalıșmaları için uygun veri tabanlarının üretilememiș olmasıdır. Geçmiște üretilen rüzgâr erozyonu değerleri ortalama değerler olarak verilmekle birlikte herhangi bir veri tabanı ve modele dayalı değerler ülkesel ölçekte niceliksel olarak verilememekteydi. Günümüzde STY ve SAY açısından erozyon kontrol çalıșmalarını planlamak, sürdürülebilir doğal kaynak kullanımını sağlamak, mühendislik çalıșmalarında kullanılmak üzere belirli konumsal ölçeklerde bilimsel ve model tabanlı erozyon risk değerlendirme çalıșmalarının yapılması zorunluluk haline gelmiștir (Erpul vd., 2016). 
Kurak ve yarı kurak alanlarda etkin koruma yöntemlerinin geliștirilmesi ve sürdürülebilir kaynak kullanımının yaygınlaștıılabilmesi için ülkesel ölçekte rüzgâr erozyonu toprak kayıplarının belirlenmesi amaçlanmıștır. Bu bağlamda iklim, toprak, arazi yönetimi, vb. faktörlerin kullanıldığı ulusal dinamik rüzgâr erozyonu modeli geliștirme çalıșmaları 2016 yılında T.C. Tarım ve Orman Bakanlığı Çölleșme ve Erozyonla Mücadele Genel Müdürlüğü (TOB, ÇEMGM) tarafından bașlatıımıștır. Türkiye ölçeğinde rüzgâr erozyonu sonucu tașınan sediment miktarının modellenmesinde YREE (Fryrear vd., 2000) esas alınarak UDREMis yazılımı geliștirilmiștir. Bu çalıșma ile bir dizi uzaktan algılama ișlemi yapılarak UDREMis ana parametrelerinden biri olan, bitki örtüsü parametresi belirlenmiștir:

\section{MATERYAL VE YÖNTEM}

\section{Çalıșma alanı}

Bilindiği üzere düz ve düze yakın alanlarda rüzgâr hızını kesecek engel olmadığında; yani farklı arazi ve toprak pürüzlülük unsurlarının bulunmadığı koșullarda rüzgâr hız parametrelerinin erozyon süreçleri üzerindeki etkisi daha șiddetli olmaktadır. Buna bağlı olarak rüzgâr erozyonunun genellikle yüzde altı (\%6) ve altındaki eğimlerde bir diğer ifade ile düz ve düze yakın geniș alanlarda meydana geldiği kabulü bulunmaktadır. Uydu görüntülerinin çerçeveler halinde temin edilmesi, Türkiye ölçeğinde NDVI değerlerinin bilinmek istenmesi ve elde edilecek NDVI değerleri kullanılarak 'Bitki Örtüsü' parametresinin hesaplanmak istenmesinden dolayı çalıșma alanı olarak Türkiye seçilmiștir. Böylece NDVI'a bağlı bir indeks ile konumsal, zamansal arazi kullanımı değișimleri ile farklı toprak ișleme sistemlerinin rüzgâr erozyonuna etkisinin ortaya konulması amaçlanmıștır.

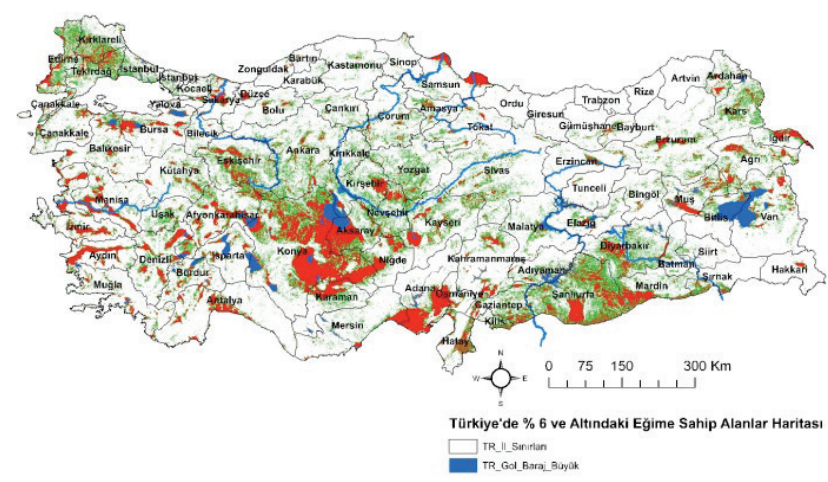

Sekil 1. Türkiye'de $\% 6$ ve Altındaki Eğime Sahip Alanlar Haritası Figure 1. Slope Map of Turkey (Sloping Fields $\leq 6$ )
Bitki örtüsü parametresinin belirlenmesinde Șekil 1'de yer alan harita dikkate alınarak \% 6 ve altındaki eğimli alanlar çalıșma alanı olarak belirlenmiștir. 10*10 m çözünürlüğe sahip Sayısal Yükselti Modeli (SYM)'den üretilen eğim haritası kullanılarak yaklașık olarak 17 milyon ha alan rüzgâr erozyonu izleme ve değerlendirme analizleri için çalıșılmıștır.

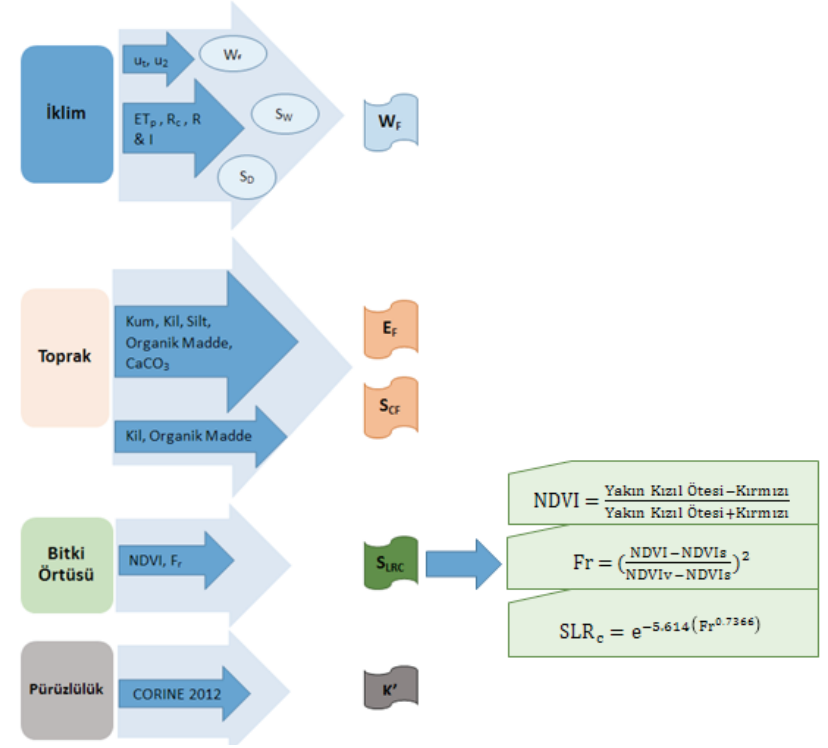

Șekil 2. YREE Modeli Parametreleri ve Akıș Șeması (Fryrear vd., 1998)

Figure 2. RWEQ Model Parameters and Flow Chart|Fryrear vd., 1998)

\section{Modelleme}

Rüzgâr erozyonu modelleme çalıșmaları Rüzgâr Erozyonu Eșitliği (REE) (Woodruff ve Siddoway, 1965) ile bașlamıștır. 1998 yılında yapılan çalıșmalar ile REE modeli güncellenerek YREE olarak kullanıma sunulmuștur. Özellikle tarım alanlarında meydana gelen toprak kayıplarını tahmin etmek amacıyla deneye dayalı, süreç temelli modellemenin bileșkesi olarak geliștirilmiștir (Fryrear vd., 1998; Fryrear vd., 2000).

ÇEM tarafından Türkiye ölçeğinde rüzgâr erozyonunun izleme ve değerlendirmesine yönelik olarak geliștirilen UDREMis yazılımı YREE modeli dikkate alınarak kurgulanmıștır.

Șekil 1'de de görüleceği üzere YREE modeli dört ana parametre ve ilișkili alt parametreleri ile çalıșarak rüzgâr erozyonu sonucu tașınan sediment miktarını tahmin etmektedir. 


\section{Uzaktan algılama ișlemleri}

UDREMis bitki örtüsü parametresinin belirlenmesi kapsamında Landsat 8 OLI uydu görüntüleri kullanılmıștır. Yersel çözünürlüğü 30 m olan bu görüntülerin Türkiye ölçeğinde yapılan çalıșma için yeterli olduğu düșünülmüștür. Kullanılan uydu görüntüleri NASA (National Aeronautical Space Administration-Ulusal Havacilık Dairesi) "https://earthexplorer.usgs. gov/" adresinden ücretsiz olarak temin edilmiștir. Landsat uydusu 16 günde dünya çevresindeki turunu tamamladığı için 16 günlük zamansal çözünürlükte görüntü alınabilmektedir. Bu bağlamda 2016 yılına ait 60 çerçevede 1440 adet görüntü ișlenmiștir (Șekil 3).

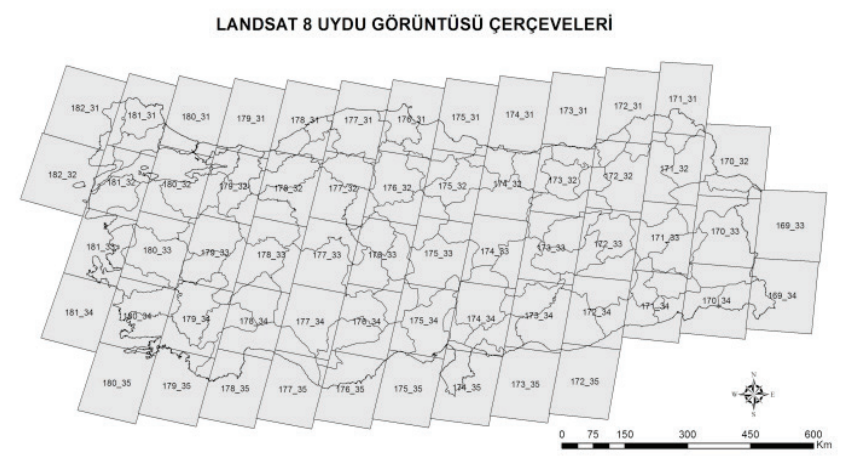

Șekil 3. Landsat Uydu Görüntüsü Çerçeveleri Figure 3. Landsat Image Frames

Uzaktan algılama çalıșmalarında, uydu görüntülerinin çekilmesi esnasında meydana gelen atmosfere bağlı etkiler, ENVı yazıımı aracııı̆ı ile giderilmiștir.

Uydu görüntülerinin çekimi esnasında meydana gelen atmosferik etkileri azaltmak için radyometrik düzeltme yapılmıștır. Radyometrik düzeltme, piksel parlaklık değerlerini, yersel spektral yansıtma değerleri ile spektral olarak karșılaștırılabilir birimlere dönüștürmektedir. (Lu vd., 2002, ENVI. 2013). (Eșitlik; [1,2,3]).

$L_{\lambda=\text { Gain } * \text { Pixel Value }+ \text { offset }} \quad 1$

$P_{\lambda}=\frac{\pi L_{\lambda} d^{2}}{E S U N_{\lambda} \sin \theta}$

$T=\frac{K 2}{\ln m\left(\frac{K 1}{L_{\lambda}}+1\right)}$
Radyasyonun dünya yüzeyi tarafından emilmesi ya da tam tersi olarak saçılmasından dolayı etkilenen uydu görüntüsü piksel ve yüzey yansıma değerlerini arındırmak için atmosferik düzeltme uygulanmıștır.

Flaash atmosferik düzeltme ile sensör değerleri yansıma değerlerine çevrilerek atmosferik düzeltme yapılmıștır. Atmosferik düzeltme esnasında görüntünün ortalama yükseltisi, uçuș zamanı ve günü, aerosol modeli gibi alt parametreleri kullanıımıștır. (Eșitlik; [4]).

$$
L=\left(\frac{A p}{1-p_{e} S}\right)+\left(\frac{B p_{e}}{1-p_{e} S}\right)+L_{a} \quad 4
$$

\section{Bitki örtüsü parametresinin belirlenmesi}

Çalıșma ile temin edilen uydu görüntüleri görüntü zenginleștirme ișlemlerinin ardından NDVI analizlerine tabi tutulmuștur. Analizler 15 günlük periyotlarla bütün yılı kapsayacak șekilde gerçekleștirilmiștir. Buda bulut ve kar örtüsünün izin verdiği alanlarda yılda 24 ayrı dönemde NDVI değeri hesaplandığı anlamına gelmektedir (Eșitlik; [5]).

\section{$N D V I=\frac{\text { Yakın Kızıl Ötesi-Kırmızl }}{\text { Yakın Kızll Ötesi }+ \text { Kırmızı }} 5$}

YREE temelli UDREMis yazılımında NDVI analizleri kullanılarak, bitki örtüsü parametresi olarak vejetasyon oranına bağlı toprak kayıpları oranı (SLRC) (Fryrear vd. 2000) dikkate alınarak hesaplanmıștır.

CBS tabanlı kurulan modelde, toprak kayıpları bitkisel örtünün veya bitki kapalıı̆ının bir fonksiyonu olarak hesaplanmaktadır. Rüzgâr erozyonu tehdidi altında olan alanların bitki örtüsü karakteristikleri ve yüzey (zemin) kapalılık oranları belirlenerek, rüzgârın bitki örtüsüne bağlı toprak kayıpları üzerindeki etkisi değerlendirilmiștir.

Vejetasyon oranı hesaplamalarında intiyaç duyulan NDVIs ve NDVIv değerleri için literatür araștırması yapılımıștır (Çizelge 1). Yapılan literatür araștırmaları ile farklı alanlarda gerçekleștirilmiș çalıșmalar sonrasında 'NDVIs 0.04 - NDVIv 0.52' değerleri ortalamasında seyrettiği görülmüștür. Buna dayanarak proje amacıyla yapılan vejetasyon oranı analizlerinde 'NDVIs 0.04 - NDVIv 0.52' alınarak model hesaplamaları yapılmıștır. Arazi üzerinde bulunan vejetasyon oranı yüzde (\%) olarak hesaplanmıștır. 
Çizelge 1. Örnek Yayınlardaki NDVIs ve NDVIv değerleri

Table 1. NDVIs and NDVIV Values at Sample Publication

\begin{tabular}{lccc}
\hline Yayın ve çalıșma alanı & NDVIs & NDVIv & Kullanılan veri \\
\hline $\begin{array}{l}\text { Gutman ve Ignatov } \\
\text { (1998)Küresel ölçek }\end{array}$ & 0.04 & 0.52 & $\begin{array}{c}\text { Global Avhrr } \\
\text { Ndvi }\end{array}$ \\
$\begin{array}{l}\text { Yang.(2006)Çin } \\
\text { Gan ve Burges (2006) }\end{array}$ & 0.05 & 0.49 & $\begin{array}{c}\text { Avhrr 10-gün } \\
\text { Ndvi }\end{array}$ \\
$\begin{array}{l}\text { Doğu ABD } \\
\text { Gebremichael (2006) }\end{array}$ & 0.04 & 0.52 & $\begin{array}{c}\text { Global Avhrr } \\
\text { Ndvi }\end{array}$ \\
$\begin{array}{l}\text { Meksika \& Nepal } \\
\text { Matsui vd. (2005) }\end{array}$ & 0.03 & 0.52 & $\begin{array}{c}\text { Global Avhrr } \\
\text { Kuzey ABD } \\
\text { Li vd. (2003) }\end{array}$ \\
$\begin{array}{l}\text { Kuzey Çin } \\
\text { Ek vd. (2003) }\end{array}$ & 0.04 & 0.61 & $\begin{array}{c}\text { Global Avhrr } \\
\text { Ndvi }\end{array}$ \\
$\begin{array}{l}\text { Kuzey ABD } \\
\text { Sridhar vd. (2003) } \\
\text { ABD }\end{array}$ & 0.04 & 0.52 & $\begin{array}{c}\text { Global Avhrr } \\
\text { Ndvi }\end{array}$ \\
\hline
\end{tabular}

Toprak kaybı miktarının hesaplanmasında ihtiyaç duyulan vejetasyon oranı girdisi Eșitlik 6 kullanılarak hesaplanmıștır (Brunsell ve Gillies., 2003; Borrelli vd., 2014).

$$
F r=\left(\frac{N D V I-N D V I s}{N D V I v-N D V I s}\right)^{2} \quad 6
$$

Burada, Fr, vejetasyon Oranı (\%); NDVI, normalize edilmiș fark bitki indeksi; NDVIs, çıplak toprak yüzeyi; NDVIv, canlı bitki örtüsü değerlerini ifade etmektedir.

Bitki örtüsüne bağlı toprak kaybı(SLRc), vejetasyon oranı (Fr) dikkate alınarak hesaplanmıștır (Eșitlik; [7]). Bu șekilde bitki örtüsü kapalılık özelliklerine bağlı olarak toprak kayıpları oranı belirlenmiștir.

$$
S L R_{c}=e^{-5.614\left(c c^{0.7366}\right)} \quad 7
$$

Burada, SLRc, Toprak Kayıpları Oranı; CC, Vejetasyon Oran'ını ifade etmektedir. Eșitlik 7'de "cc" değeri yerine, Eșitlik 6'da elde edilen " $F r^{\prime}$ değeri yazılarak sonuca ulașılmıștır.

\section{BULGULAR VE TARTIȘMA}

Türkiye ölçeğinde YREE modelinin ana çatısını olușturduğu UDREMis sistemi bitki örtüsü parametresi üretilmiștir (Șekil 4). İlgili haritalarda bitki örtüsünün rüzgâr erozyonuna duyarlılığı 0 ile 1 arasında ölçeklendirilmiștir. '1' değerine yakın olan pikseller rüzgâr erozyonuna en duyarlı 'O' değerine yakın olan pikseller ise en az duyarlı yani rüzgâr erozyonunun en az etkileyeceği alanları ifade etmektedir. Nisan ve Haziran aylarında düșük olan erozyon duyarlılığı ürünlerin hasat edilmesi ve vejetasyonun zayıflaması ile Haziran ayından itibaren artmaktadır. Küresel iklim değișikliği ile yıllık yağıș ve sıcaklık seyri değișmektedir. Buna bağlı olarak geç kalan sonbahar yağıșları araziyi rüzgâr erozyonuna açık hale getirmektedir.

Șekil 5'de Türkiye aylık ortalama SLRc değerleri gösterilmiștir. SLRc değerinin en düșük olduğu ay Mayıs en yüksek olduğu ay ise Aralık olarak görülmektedir. İlkbahar ayları itibari ile bitki örtüsünün canlanmasına paralel olarak arazi kapalııkları artmakta ve rüzgâr erozyonuna duyarlılık düșmektedir.

Sekil 4'de de aylık SLRc haritaları sunulmuștur. Kıș mevsimine ait aylarda Özellikle Ocak ve Șubat aylarında kar örtüsünden dolayı yüksek alanlarda NDVI değerleri normalden sapmıș olup SRLC değerleri l'e yakın görünmektedir (Șekil 4).Bu nedenle haritalarda kıș aylarında kırmızı renk göze çarpmaktadır. Görüntülerin Türkiye ölçeğinde elde edilmesi ve ișlenmesine rağmen UDREMis modelinde ( $\leq \% 6$ eğim) potansiyel rüzgâr erozyonu alanlarında kar örtüsünün yarattığı olumsuz etki görülmemektedir.

Coğrafi bölgeler bazında aylık ortalama SLRc değerleri Ege, Güneydoğu Anadolu ve Marmara bölgelerinde SLRc değerleri minimum değere Nisan ayında ulașmaktadır. Buda ülkemizde iklim, yükselti güneșlenme süreleri ile ilgili olarak vejetasyon sürelerinde farklıık olduğunu göstermektedir. Akdeniz, Ege, Karadeniz, Marmara bölgelerinin duyarlılıklarını etkileyen coğrafi șartlar nedeniyle yıl içerisinde belirli bir ortalama değerin üzerine çıkılmadığı görülmektedir. Çizelge 2'de belirtildiği gibi İç Anadolu, Güneydoğu Anadolu ve Doğu Anadolu Bölgeleri bitki örtüsü duyarlılığı bakımından kırılgan bir yapıya sahiptir. 

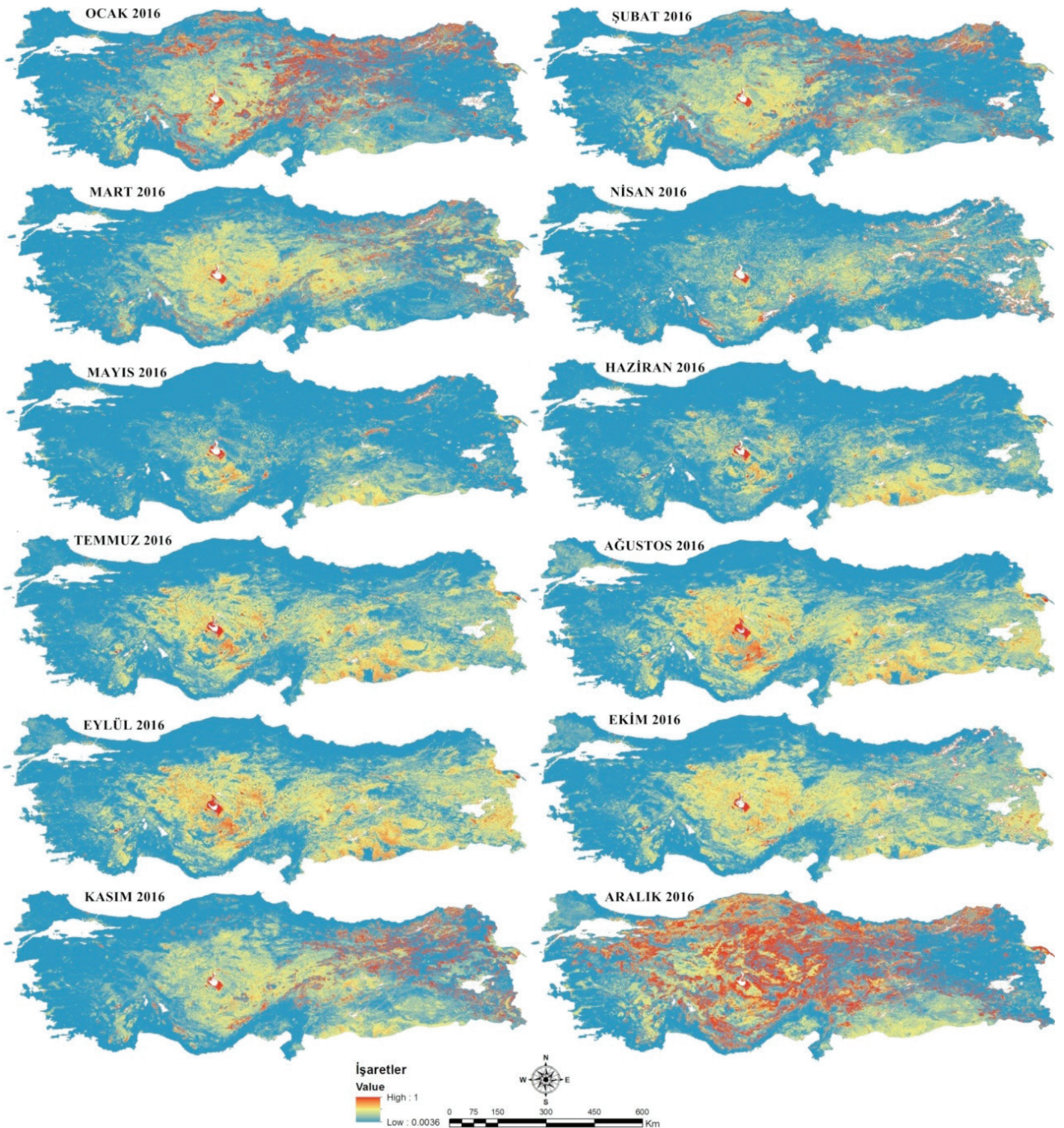

Sekil 4. Türkiye Aylık Ortalama Bitki Örtüsü (SLRc) Katmanı

Figure 4. Turkey Monthly Average Vegetation (SLRC) Layer

Çizelge 2. Aylar İtibari ile Coğrafi Bölgelere Göre Ortalama Bitki Örtüsü Duyarlılığı

Table 2. Monthly Average Vegetation Sensitivity by Geographical Regions

\begin{tabular}{lccccccccccccc}
\hline Coğrafi Bölgeler & Oca. & Șub. & Mar. & Nis. & May. & Haz. & Tem. & Ağu. & Eyl. & Eki. & Kas. & Ara. & Ort. \\
\hline Akdeniz Bölgesi & 0.16 & 0.17 & 0.15 & 0.10 & 0.06 & 0.08 & 0.11 & 0.13 & 0.12 & 0.12 & 0.12 & 0.26 & 0.13 \\
D. Anadolu Bölgesi & 0.59 & 0.55 & 0.38 & 0.21 & 0.07 & 0.10 & 0.19 & 0.21 & 0.25 & 0.26 & 0.45 & 0.49 & 0.31 \\
Ege Bölgesi & 0.10 & 0.10 & 0.08 & 0.04 & 0.04 & 0.05 & 0.07 & 0.10 & 0.09 & 0.08 & 0.06 & 0.19 & 0.08 \\
GD. Anadolu Bölgesi & 0.18 & 0.19 & 0.12 & 0.09 & 0.20 & 0.26 & 0.29 & 0.32 & 0.31 & 0.27 & 0.25 & 0.34 & 0.23 \\
Iç Anadolu Bölgesi & 0.38 & 0.34 & 0.34 & 0.18 & 0.12 & 0.14 & 0.24 & 0.30 & 0.29 & 0.32 & 0.29 & 0.39 & 0.28 \\
Karadeniz Bölgesi & 0.34 & 0.24 & 0.12 & 0.05 & 0.02 & 0.02 & 0.04 & 0.04 & 0.05 & 0.07 & 0.14 & 0.55 & 0.14 \\
Marmara Bölgesi & 0.04 & 0.04 & 0.03 & 0.02 & 0.02 & 0.02 & 0.03 & 0.06 & 0.04 & 0.04 & 0.02 & 0.24 & 0.05 \\
\hline
\end{tabular}




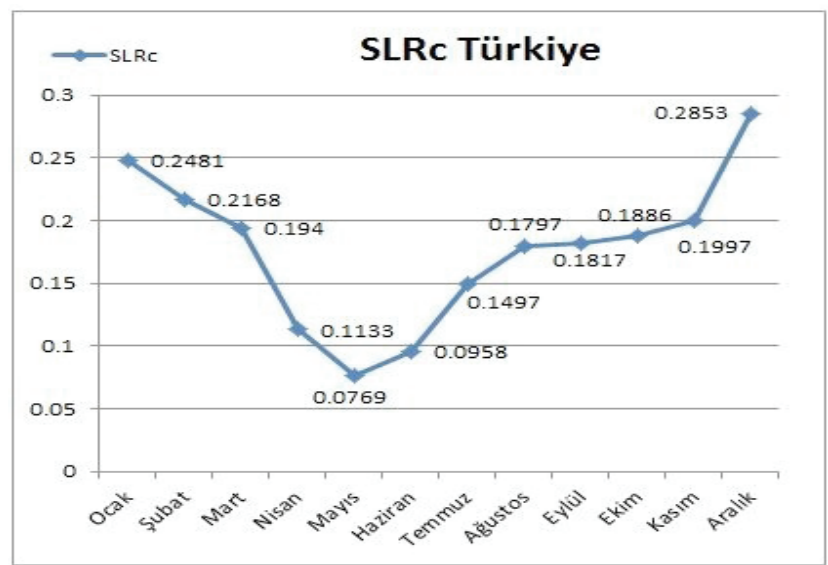

Șekil 5. Türkiye Geneli Ortalama Bitki Örtüsü Bakımından Rüzgâr Erozyonuna Duyarlılık

Figure 5. Monthly Average Vegetation Cover Wind Erosion Sensitivity

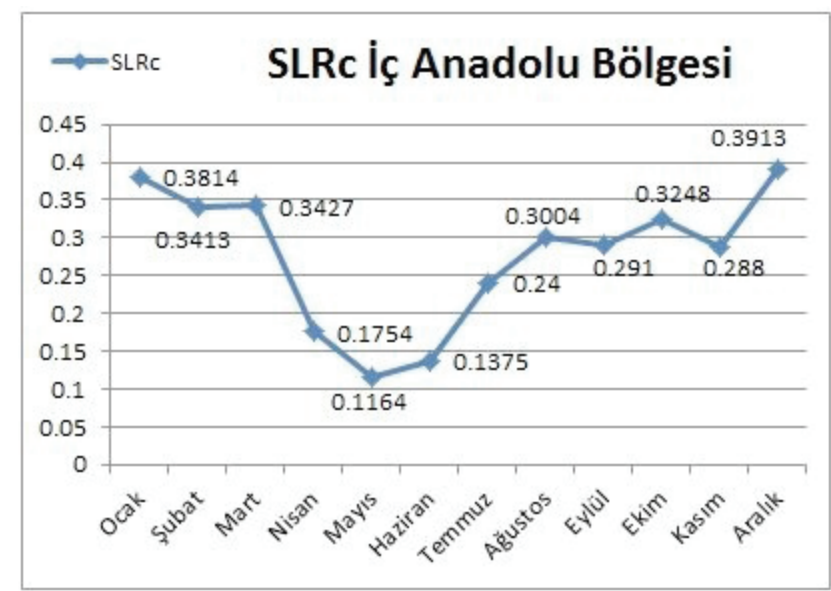

Șekil 6. İç Anadolu Bölgesi Bitki Örtüsü Bakımından Rüzgâr Erozyonuna Duyarlılık

Figure 6. Monthly Vegetation Sensitivity in Central Anatolia Region

Coğrafi bölgeler bazında aylık ortalama SLRc değerleri Ege, Güneydoğu Anadolu ve Marmara bölgelerinde SLRc değerleri minimum değere Nisan ayında ulașmaktadır. Buda ülkemizde iklim, yükselti güneșlenme süreleri ile ilgili olarak vejetasyon sürelerinde farklılık olduğunu göstermektedir. Akdeniz, Ege, Karadeniz, Marmara bölgelerinin duyarlılıklarını etkileyen coğrafi șartlar nedeniyle yıl içerisinde belirli bir ortalama değerin üzerine çıkılmadığı görülmektedir. Çizelge 2'de belirtildiği gibi İç Anadolu, Güneydoğu Anadolu ve Doğu Anadolu Bölgeleri bitki örtüsü duyarlıı̆ı bakımından kırılgan bir yapıya sahiptir.
Ị̇ Anadolu Bölgesinde görülen yüksek duyarlıık değerleri özellikle çıplak alanlarda ilkbahar mevsimine kadar rüzgâr erozyonuna zemin hazırlayacaktır (Șekil 6).

\section{SONUC̣LAR}

Coğrafi bilgi sistemleri ve uzaktan algılama yöntemlerinin etkileșimli bir șekilde kullanılması ile YREE model yapısına göre bitki örtüsü parametresi belirlenmiș olup UDREMis sisteminin kullandığı analitik veri altıkları sayesinde rüzgâr erozyonuna bağlı arazi bozulmasının görüldüğü alanlarda erozyon miktarının niceliksel olarak alınabilmesi sağlanmıștır.

YII içerisinde 16 günde bir elde edilen veriler kullanılarak farklı dönemlerdeki bitki örtüsü duyarlılı̆ı belirlenmiștir. Türkiye ölçeğinde yapılacak çalıșmalar için kıș aylarına ait görüntülerde bulutluluk ve kar örtüsünden dolayı ilgili ay içerisindeki en temiz görüntüler seçilerek birleștirilmiștir. Buda Türkiye ölçeğinde aylık tek görüntü elde edilmesine neden olmuștur.

Daha öncede belirtildiği üzere çalıșmanın asıl amacı rüzgâr erozyonu potansiyeline sahip $\leq$ \%6 eğimli alanlarda bitki örtüsü parametresinin belirlenmesi olduğundan dolayı alan tüm ülke yüzeyi olmadığı için beklenen zamansal ve mekânsal çözünürlükte veriler proje kapsamında üretilebilmiștir. Bölge veya ova gibi büyük ölçekli alanlarda yapılacak çalıșmalarda da daha fazla zamansal ve mekânsal veriler ile çalıșılabilecektir. Türkiye ölçeğinde yapılacak çalıșmalar için Șekil 4'de de görüldüğü üzere aylık SLRc katmanı üretilmiș olup intiyaç duyan araștırmacılar için ileriki çalıșmalarında yarar sağlayacağı düșünülmektedir.

STY, SAY ve ATD bakımından arazi kullanımı planlamalarının yapılabilmesi için büyük öneme sahip altıklar olarak da değerlendirilebilecek bu çalıșma verileri aynı zamanda yapılacak benzer proje ve çeșitli politikaların üretilmesinde de kullanılabilecektir.

\section{KAYNAKCุA}

Borrelli P, Ballabio C, Panagos P, Montanarella L (2014). Wind erosion susceptibility of european soils. Geoderma, 232: $471-478$.

Brunsell NA, Gillies RR (2003). Scale issues in landatmosphere interactions: implications for remote sensing of the surface energy balance. Agricultural and Forest Meteorology, 117: 203-221. 
Ek MB, Mitchell KE, Lin $Y$, Rogers E, Grunmann P, Koren $V$ (2003). Implementation of $\mathrm{NOAH}$ land surface model advances in the National Centers for Environmental Prediction operational mesoscale Eta model. Journal of Geophysical Research, 108: 12-11 to 1216.

ENVI (2009). User Guide Tutorial. Available: http://www. harrisgeospatial.com/portals/0/pdfs/envi/ENVI_User_Guide. pdf (23.12.2019).

Erpul G, Saygın SD (2012). Ülkemizdeki toprak erozyonu sorunu üzerine: Ne yapmalı? Toprak Bilimi ve Bitki Besleme Dergisi, Türkiye Toprak Bilimi Derneği, 1, (1): 26-32.

Erpul G, Șahin S, Akgöz R, İnce K, Güden A, Çetin E (2016). Türkiye yağıșlarının özellikleri ve Yenilenmiș Evrensel Toprak Kayıpları Eșitliği (YETKE) R faktörü, Ankara, s: 10-22.

Fryrear DW, Bilbro JD, Saleh A, Schomberg H, Stout JE, Zobeck TM (2000). RWEQ: improved wind erosion technology. Journal of Soil and Water Conservation 55: 183189.

Fryrear DW, Saleh A, Bilbro JD, Schomberg HM, Stout JE, Zobeck TM (1998). Revised Wind Erosion Equation (RWEQ). Technical Bulletin 1, Southern Plains Area Cropping Systems Research Laboratory, Wind Erosion and Water Conservation Research Unit, USDA-ARS.

Gan TY, Burges SJ (2006). Assessment of soil-based and calibrated parameters of the Sacramento model and parameter transferability. Journal of Hydrology, 320: $117-$ 131

Gebremichael M, Barros AP (2006). Evaluation of MODIS Gross Primary Productivity (GPP) in tropical monsoon regions. Remote Sensing of Environment, 100: 150-166.

Gutman G, Ignatov A (1998). The derivation of the green vegetation fraction from NOAAAVHRR data for use in numerical weather prediction models. International Journal of Remote Sensing, 19: 1533-1543.

İnce K, Akgöz R, Erpul G, (2019). Türkiye'de rüzgâr erozyonu nedeniyle olușan toprak kayıplarının model tabanlı mekânsal ve zamansal değișiminin belirlenmesi. Iğdır Üniversitesi Fen Bilimleri Enstitüsü Dergisi, 9, (4): 2336-2345
Lal R (1990). Soil erosion in tropics: Principles and management. McGrawlnc., New York.

Lal R, (2001). Soil Degradation By Erosion. Wiley Online Library, December, $519-539$.

Li XB, Chen YH, Shi PJ, Chen J(2003). Detecting vegetation fractional coverage of typical steppe in northern China based on multi-scale remotely sensed data. Acta Botanica Sinica, 45: $1146-1156$.

Lu D, Mausel P, Brondizıo E, Moran E (2002). Assessment of atmospheric correction methods for Landsat TM data applicable to Amazon basin LBA research, International Journal of Remote Sensing, 23: 1671-2651.

Matsui T, Lakshmi V, Small EE (2005). The effects of satellite-derived vegetation cover variability on simulated land-atmosphere interactions in the NAMS. Journal of Climate, 18: 21-40.

Reich P, Eswaran H, Beinroth F (2000). Global dimensions of vulnerability to wind and watererosion. Proceedings of the 2nd International Conference On Land Degradation, Khon Kaen, Thailand, January, 25-29.

Sridhar V, Elliott RL, Chen F (2003). Scaling effects on modeled surface energy-balance components using the $\mathrm{NOAH}-\mathrm{OSU}$ land surface model. Journal of Hydrology, 280: 105-123.

Stroosnijder L (2007). Rainfall and land degradation in Sivakumar, MVK and N. Ndiang'ui (Eds.) Climate and land degradation, Springer, 167-195.

Woodruff NP, Siddoway FH (1965). A wind erosion equation. Soil Science Society of America Journal. Proc. Vol: 29: 602-608.

Yang $H$, Yang $Z$ (2006). A modified land surface temperature split window retrieval algorithm and its applications over China. Global and Planetary Change, 52: 207-215. 